\title{
Soil Solarization as a Component of an Integrated Program for Control of Raspberry Root Rot
}

\author{
J. N. Pinkerton, USDA-ARS, HCRL, Corvallis, OR 97330; P. R. Bristow and G. E. Windom, Washington State \\ University, Puyallup Research and Extension Center, Puyallup, WA 98371; and T. W. Walters, WSU-Mount Vernon \\ NWREC, Mt Vernon, WA 98273
}

\begin{abstract}
Pinkerton, J. N., Bristow, P. R., Windom, G. E., and Walters, T. W. 2009. Soil solarization as a component of an integrated program for control of raspberry root rot. Plant Dis. 93:452-458.

Field and growth chamber studies were conducted during 2000 to 2005 to determine the efficacy of soil solarization for the control of Phytophthora root rot of raspberry (PRR). The exposure time that was lethal to Phytophthora rubi cultures on V8 juice agar plates was evaluated at intervals up to $240 \mathrm{~h}$ and at a range of temperatures from 20 to $35^{\circ} \mathrm{C}$. Colonies incubated at 20 and $25^{\circ} \mathrm{C}$ nearly covered the plates in $240 \mathrm{~h}$, while radial growth slowed at $27^{\circ} \mathrm{C}$ and ceased at temperatures $\geq 29^{\circ} \mathrm{C}$. The exposure times required to kill P. rubi were estimated to be $222 \mathrm{~h}$ at $29^{\circ} \mathrm{C}$, $168 \mathrm{~h}$ at $31^{\circ} \mathrm{C}, 108 \mathrm{~h}$ at $33^{\circ} \mathrm{C}$, and $52 \mathrm{~h}$ at $35^{\circ} \mathrm{C}$. Previous exposure to shorter durations at temperature $\geq 29^{\circ} \mathrm{C}$ slowed growth of colonies when they later were incubated at $20^{\circ} \mathrm{C}$. Field trials were established in 2000 and 2003 at three locations in Washington State to evaluate soil solarization for the management of PRR. Cumulative hours with soil temperatures $>29^{\circ} \mathrm{C}$ at $30 \mathrm{~cm}$ soil depth in solarized plots exceeded $200 \mathrm{~h}$ in each trial. In the 2000 trial, combinations of solarization, bed shape, and amendments of gypsum were evaluated. Over the 3 years after planting PRR-susceptible raspberry 'Malahat' and 'Willamette', primocane growth and survival were greater $(P<0.05)$ in raised bed plots that were solarized than in solarized and nonsolarized flat bed plots or hilled bed plots with gypsum. In 2003, trials were initiated to evaluate solarization in combination with applications of mefenoxam and fosetyl-Al. In 2004, solarization increased $(P<0.05)$ primocane growth of 'Malahat' and 'Qualicum' raspberries at both locations compared to application of fungicides alone and nontreated control plots. At both locations in 2005, density and growth of 'Qualicum' primocanes were greatest in solarized plots, while canes in solarized and fungicide only plots of 'Malahat' were similar. Incidence of diseased canes was lowest in plots that received fungicides. Primocane survival and fruit yields were very low at both locations in the third season because of favorable conditions for PRR and plant stress in late spring. These results indicate that soil solarization can be an effective component of integrated management of PRR in the Pacific Northwest, especially when combined with raised beds and gypsum amendments.
\end{abstract}

Raspberry root rot (PRR), caused by Phytophthora spp., can cause economic losses in cool, wet production areas $(6,12,19,35,36)$. These pathogens reduce plant vigor, decrease yields, and can cause large areas in fields to die out in one or two seasons. PRR caused by Phytophthora spp. was first reported in the Pacific Northwest (PNW) in 1968 (6). The predominant species isolated from raspberry in the PNW is Phytophthora rubi (Basionym Phytophthora fragariae var. rubi).

Corresponding author: J. N. Pinkerton

E-mail: Jack.Pinkerton@ARS.USDA.GOV

Accepted for publication 1 January 2009.

doi:10.1094/PDIS-93-5-0452

This article is in the public domain and not copyrightable. It may be freely reprinted with customary crediting of the source. The American Phytopathological Society, 2009.
Management of PRR is difficult because oospores of $P$. fragariae may persist in field soil for many years, limiting the efficacy of crop rotations for disease control $(8,36)$. Soil fumigation with methyl bromide may delay the onset of root rot in red raspberry plantings by only 3 to 4 years (15). In addition, isolates of $P$. fragariae which are resistant to metalaxyl (Ridomil, Ciba, Greensboro, NC) have been found in strawberry plantings in the PNW (27). Disease control is markedly reduced in some Washington fields when raspberries are replanted into soil with a history of metalaxyl use (P. Bristow, unpublished data). Metalaxyl has been shown to be ineffective for controlling PRR under high disease pressure (38). These limitations leave the raspberry industries searching for alternative management tools for root rot control.

Alternative management tools include host resistance, hilling, and amendment with gypsum (39). Another management tool, soil solarization, is a process that employs solar radiation to heat soil under a transparent plastic film to temperatures that are detrimental to soilborne pathogens (17). Solarization targets mesophyllic organisms, which include most plant pathogens and pests, without destroying thermotolerant fungi and Bacillus spp. (17). Changes in the microflora following solarization may account for enhanced plant growth and induced suppressiveness to plant pathogens $(14,29)$. Solarization can enhance the effectiveness of other pest management approaches $(4,30)$ and has the additional advantages of being a nonchemical alternative for pathogen control.

In Oregon and Washington, solarization has shown promise for the control of soilborne plant pathogenic fungi, bacteria, nematodes, and weeds affecting nursery and small fruit crops (21-23). Introduced populations of Verticillium dahliae, Pratylenchus penetrans, and Agrobacterium tumefaciens were significantly reduced in solarized plots, and Phytophthora cinnamomi was not recovered from the test soils following solarization (22). Soil solarization also showed promise for managing root diseases of raspberry and strawberry, including those caused by $P$. fragariae and P. rubi (23). An integrated program utilizing raised beds, gypsum amendments, and fungicide applications provided the best control of raspberry root rot in New York State (18). These management inputs are compatible with, and may be enhanced by, soil solarization. The objectives of this research were to determine the lethal thermal exposure for growth of $P$. rubi and to evaluate soil solarization as a component of an integrated program for reducing populations of root rot pathogens before planting raspberry.

\section{MATERIALS AND METHODS}

In vitro growth study. Colony growth rate and survival studies were conducted over a range of temperature doses, i.e., temperature $\times$ incubation duration. An isolate of $P$. rubi originally collected from red raspberry in Clark County near Vancouver, WA and described as P. erythroseptica (6) was transferred to petri dishes of 
V8 $(6 \%)$ juice agar and incubated at 20 to $24^{\circ} \mathrm{C}$. After 7 days, 5-mm-diameter cores were cut from the margin of the actively growing colonies with a sterile no. 3 cork borer and placed in the center of 100-mmdiameter petri dishes containing V8 juice agar (one core per dish). The petri dishes were placed in incubators set at 20, 25, 27, $29,31,33$, or $35^{\circ} \mathrm{C}\left( \pm 0.4^{\circ} \mathrm{C}\right)$ for 12,24 , $36,48,72,96,120,144,196$, or $240 \mathrm{~h}$. Temperature $\times$ exposure times were evaluated with three replicate dishes for each treatment combination, and the experiment was conducted twice. Diameters of colonies in the dishes (maximum $80 \mathrm{~mm}$ ) were recorded at the end of each incubation period and again at 48 -h intervals after plates were transferred to $20^{\circ} \mathrm{C}$.

Field solarization studies. Field trials were conducted in three locations that represented the northern to southern $(\sim 400$ $\mathrm{km}$ ) distribution and climatic ranges of red raspberry production in western Washington. Sites were cropped previously with red raspberry and had histories of stand decline caused by PRR. In 2000, a trial was established at the WSU-Vancouver Research and Extension Unit in Clark County (Southwestern Washington, $45^{\circ} 40^{\prime} \mathrm{N}, 122^{\circ} 39^{\prime} \mathrm{W}$ ) to evaluate an integrated management program utilizing solarization, bed architecture, and gypsum amendments. In 2003, identical trials were established at the WSU Puyallup Research and Extension Center in Pierce County (Western Washington, $47^{\circ} 11^{\prime} \mathrm{N}, 122^{\circ} 13^{\prime} \mathrm{W}$ ) and in a commercial raspberry field in rural Whatcom County (Northwestern Washington, $48^{\circ} 54^{\prime} \mathrm{N}, \quad 122^{\circ} 19^{\prime} \mathrm{W}$ ) to evaluate solarization with and without fungicide applications to manage root rot. Symptomatic plants from all three locations tested positive for $P$. rubi by enzymelinked immunosorbent assay (ELISA) and polymerase chain reaction (PCR) (C. MacConnell, personal communication).

Clark County solarization trial. The trial was situated on Hillsboro silt loam soil (fine silty, mixed, superactive, Mesic, Ar-

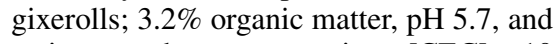
cation exchange capacity [CEC] 10 meq/100 g) which was naturally infested with $P$. rubi and had been used for numerous PRR field trials $(3,31)$. The area was planted in grass for several years before it was plowed and disked in mid-July 2000. The experiment included six treatments: two bed types (raised or flat beds), two solarization treatments (solarized or nonsolarized), two amendment treatments (gypsum or no gypsum), and nontreated controls in a split block design across six rows and with four replicates. Gypsum amendments were not evaluated in the plots with flat beds. Plots were $10 \times 3.9 \mathrm{~m}$ with 1.5 $\mathrm{m}$ borders between rows and $1 \mathrm{~m}$ between plots in rows. On 26 July, granular (prilled) agricultural gypsum was applied in a 2.4$\mathrm{m}$ band in the center of raised bed plots with a Gandy drop spreader at 13,450 $\mathrm{kg} / \mathrm{ha}$ and incorporated by rotovating to a depth of $20 \mathrm{~cm}$. Raised beds 1 to $1.2 \mathrm{~m}$ wide by $30 \mathrm{~cm}$ high were formed with a tractor drawn bed shaper which drew soil from a $2.9-\mathrm{m}$ width of the plots. Soil was irrigated with ca. $10 \mathrm{~mm}$ of irrigation via overhead sprinklers. On 27 July 2000, a 0.05-mm-thick clear polyethylene film (Tyco Nursery Supply, City of Industry, CA) was stretched across the soil surface of plots to be solarized and secured in place by burying the edges. The remaining plots in each replication were maintained in bare fallow as nonsolarized controls. Thermocouples were buried at 10 and 30 $\mathrm{cm}$ in one solarized and one nonsolarized plot. Hourly temperature data were recorded through 20 September with a datalogger (Campbell Scientific, Logan, UT).

Tarps were rolled back to leave a $1.5-\mathrm{m}$ alleyway between the planting rows which was planted with tall fescue (Fescue arundinacea) on 5 October 2000. On 17 May 2001, the film was removed and the plots were rotovated to a depth of $10 \mathrm{~cm}$ with a garden rototiller. All solarized plots were tilled before nonsolarized plots to eliminate the movement of nonsolarized soil into solarized plots. Five plants of highly susceptible raspberry cultivars Malahat and Willamette (31) were planted on 60$\mathrm{cm}$ spacing in opposite halves of the plots. Drip irrigation tubing and a trellis system were installed at this time. Plants were maintained with recommended fertilizer and management practices throughout the experiment (28). Weed density in plots was estimated on 7 July 2001 by rating weed groundcover on a scale of 0 to $5(0=$ no weed cover, $1=20 \%$, up to $5=100 \%$ groundcover). After this weed evaluation through the end of the experiment, weeds were managed by hand weeding and applications of glyphosate (Roundup; Monsanto, St. Louis, MO).

Effects of treatments were evaluated for 3 years by annually counting canes, measuring cane lengths or weight, and collecting fruit yield data in the third year. On 15 October 2001, primocanes in each plot were cut to the ground, and total cane weight of each cultivar was recorded. In 2002, number of primocanes of each plant cultivar per hill, number canes per plot, and height of 50 canes per plot were recorded on 14 June, 12 August, and 18 October, respectively. During the final year, canes per plot were counted on 22 May and 6 November. Fruit was machine harvested 11 times between 28 June and 17 July 2003.

Pierce and Whatcom county trials. The Whatcom County trial was in a field cropped with red raspberries for the previous 20 years. Plants showed symptoms of root rot the last 5 years. The soil was a well-drained Orida silt loam (coarse-silty, mixed superactive, nonacid, Mesic Fluvaquentic, Endoaquepts; $3.5 \%$ organic matter, pH 5.1, and CEC 10.2 meq/100 g). A single 200-m row of raspberries in the plantings was removed, soil was tilled, and a 10-cm-high raised bed was formed by hand in early July 2003 in the center of this row. The Pierce County trial was established in a site that had been used for raspberry root rot research, but had been planted in grass for the 2 years prior to the solarization trial. The plot area was plowed to incorporate the sod and rotovated to form a flat bed in early July 2003. The soil type was a Sultan silt loam (fine-silty, isotic, Mesic, Aquardic Dystroxerepts; $3.1 \%$ organic matter, $\mathrm{pH} 5.9$, and CEC $13.0 \mathrm{meq} / 100 \mathrm{~g})$. The experimental design at both locations was a randomized complete block with four replicates. Treatments included solarized and nonsolarized plots, each with and without application of the fungicides mefenoxam (Ridomil Gold; Ciba, Greensboro, NC) and fosetyl-Al (Aliette; Bayer CropScience, Research Triangle Park, NC). Individual plots of 7.6 $\times 3 \mathrm{~m}$ (Pierce) and $9.2 \times 3 \mathrm{~m}$ (Whatcom) were arranged along a single row. A 1.8-m border was left on either side of the plot row.

Plot areas were irrigated the day before laying the solarization film. Thermocouples were buried at 10 and $30 \mathrm{~cm}$ depths in one solarized and one nonsolarized plot, and hourly temperatures were recorded with mini-dataloggers (HOBO; Onset Computer Corp., Pocasset, MA). The film was laid on 22 and 23 July 2003 at Pierce and Whatcom county plots, respectively. Shallow trenches $(10 \mathrm{~cm})$ were dug at the perimeter of the plots to be solarized, the film was stretched over the plots, and the trenches were backfilled to secure the edges of the film.

Temperature recorders were removed from the plots in September. The film was removed in February 2004 at the Whatcom site and 27 April at the Pierce site. Plots were rotovated to a depth of $10 \mathrm{~cm}$ with a garden rototiller. All solarized plots were tilled before nonsolarized plots to eliminate the movement of nonsolarized soil into solarized plots. Two root rot susceptible raspberry cultivars $(3,31)$ were planted on 13 May (Pierce) and 14 May (Whatcom): field grown 'Malahat' and tissue culture propagated 'Qualicum' plants (supplied by Sakuma Bros., Burlington, WA). Five (Pierce) or six (Whatcom) plants of each cultivar were planted along the centerline of the plots on $60-\mathrm{cm}$ spacing at opposite ends of each plot. In plots that received fungicide treatments, mefenoxam (118.3 ml formulated mefenoxam in 3,785 liters of water per $304.8 \mathrm{~m}$ of row) was applied to the surface of the soil in a 0.9-m-wide band centered on the plant row during a period of rain in the spring and fall each year. Fosetyl-Al (5.7 formulated $\mathrm{kg} / \mathrm{ha}$ in 190 liters of water) was sprayed on the leaves and canes twice at approximately 4-week intervals each spring and fall. Weeds were managed through the 
study with hand-hoeing and applications of glyphosate. Trellis systems were installed and the canes thinned and trained in February 2006. Plants were maintained with recommended fertilizer and management practices (28) throughout the experiment.

Effects of treatments were evaluated for 3 years. The survival of hills and the num- ber of canes per hill were recorded on 26 August 2004. Primocanes were cut to the ground on 2 December (Pierce) and 27 December 2004 (Whatcom), and the number of canes, cane lengths, and weight were recorded for canes in each surviving hill. The number of primocanes per hill was counted on 18 April 2005. The num-

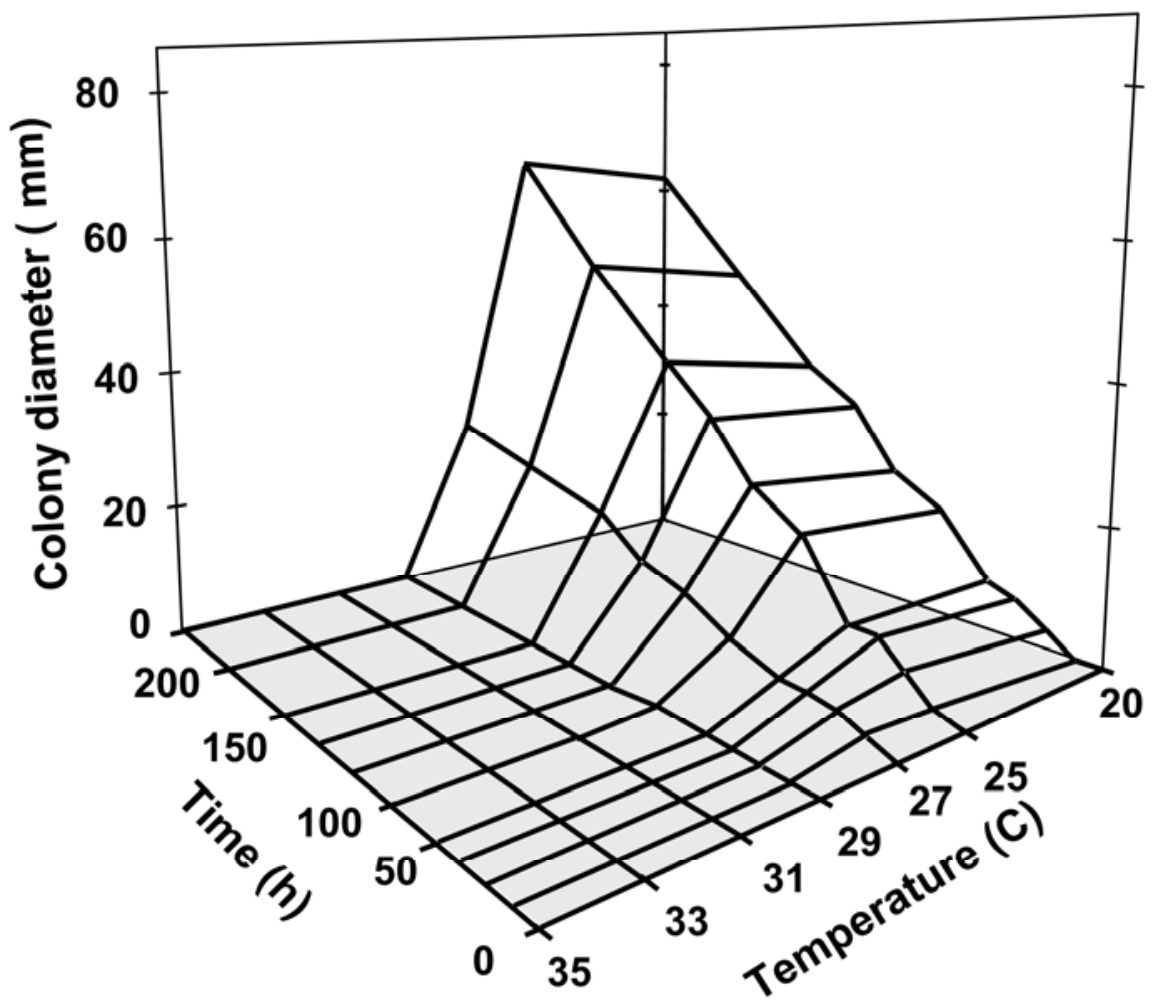

Fig. 1. Growth of colonies of Phytophthora rubi on V8 juice agar incubated for 0 to $240 \mathrm{~h}$ at 20 to $35^{\circ} \mathrm{C}$. Maximum growth is $80 \mathrm{~mm}$.

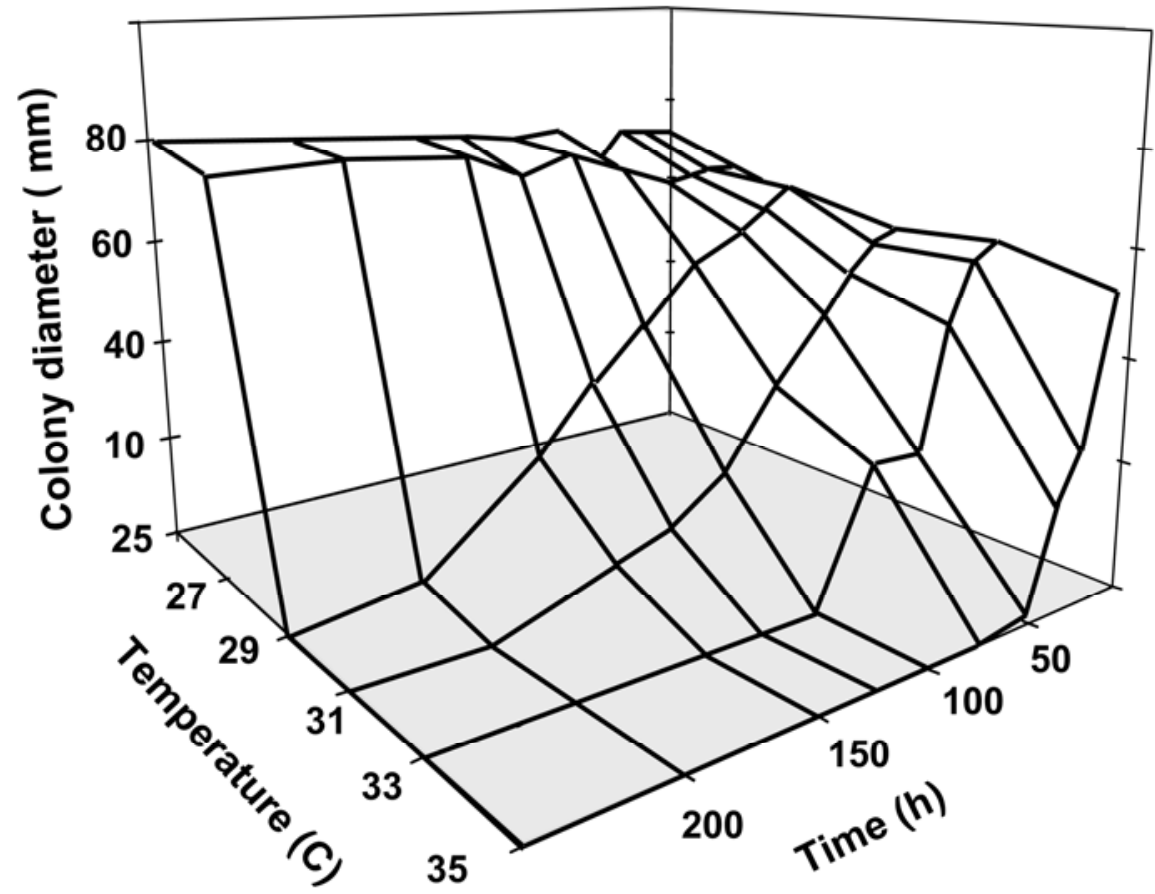

Fig. 2. Growth of colonies of Phytophthora rubi on V8 juice agar after exposure at temperatures from 25 to $35^{\circ} \mathrm{C}$ for 0 to $240 \mathrm{~h}$ and then incubation at $20^{\circ} \mathrm{C}$ for an additional $240 \mathrm{~h}$. Maximum growth is $40 \mathrm{~mm}$.

ber of primocanes and the percentage of canes with symptoms of root rot were recorded on 16 August. On 13 December, the height of 50 primocanes in two $50-\mathrm{cm}$ sections of the row in each plot was recorded. In 2006, the Whatcom County plots were machine harvested and fruit yield data were collected on three dates between 22 June and 18 July 2006. Because of poor plant survival at Pierce County, plots were not harvested, but fruit load was estimated once on 28 June (rated $1=$ no fruit to $10=$ typical commercial fruit load). The number and mean heights of primocanes $>8 \mathrm{~mm}$ diameter was recorded on 7 July 2006 at both locations.

Statistical analysis. For each sample date in field trials, cane survival and growth and fruit yield data were analyzed by Multifactor ANOVA using GLM procedures, and means were separated using Fisher's protected LSD procedure (Statgraphics Plus version 5; Manugistics Inc., Rockville, MD). The duration of exposure at each temperature required to kill colonies in the in vitro study was estimated as the $\mathrm{x}$-intercept of a linear regression model of the incubation time and the diameter of the colonies after additional periods of incubation at $20^{\circ} \mathrm{C}$. Colony growth data from the two experiments were combined for analysis. Response surface figures of the relationship of thermal dose to colony growth were graphed using Sigma Plot software (version 10; Systat Software, Inc., San Jose, CA).

\section{RESULTS}

In vitro growth study. The growth patterns of the two replicates were not different $(P<0.05)$ over the range of temperature tested. The rate of colony growth was linear at 20,25 , and $27^{\circ} \mathrm{C}\left(R^{2}>0.99\right)$ with growth rates of $0.140,0.144$, and $0.05 \mathrm{~mm}$ $\mathrm{h}^{-1}$, respectively (Fig. 1). Colonies nearly covered the surface of the medium after $240 \mathrm{~h}$ at 20 and $25^{\circ} \mathrm{C}$. Colonies incubated at $29^{\circ} \mathrm{C}$ grew less than $1 \mathrm{~mm}$ in $240 \mathrm{~h}$, and no growth was observed at 31 to $35^{\circ} \mathrm{C}$. After incubation at each temperature, colony growth resumed when cultures were returned to $20^{\circ} \mathrm{C}$ and incubated for $240 \mathrm{~h}$ (Fig. 2). Exposure time had little effect on cultures incubated at 25 and $27^{\circ} \mathrm{C}$, i.e., colonies reached 95 to $100 \%$ maximum growth after $240 \mathrm{~h}$ at $20^{\circ} \mathrm{C}$. After exposure to test temperatures $\geq 29^{\circ} \mathrm{C}$, colony growth was suppressed upon return of colonies to $20^{\circ} \mathrm{C}$, and the degree of suppression increased with increasing duration of exposure to high temperature. Radial growth was reduced to $22,11.6,2$, and $0.8 \mathrm{~mm}$ by exposure to $29^{\circ} \mathrm{C}$ for $96,144,192$, and 240 $\mathrm{h}$, respectively. The exposure times required to kill the fungi were estimated as $222 \mathrm{~h}$ at $29^{\circ} \mathrm{C}\left(R^{2}=97\right), 168 \mathrm{~h}$ at $31^{\circ} \mathrm{C}\left(R^{2}\right.$ $=91), 108 \mathrm{~h}$ at $33^{\circ} \mathrm{C}\left(R^{2}=91\right)$, and $52 \mathrm{~h}$ at $35^{\circ} \mathrm{C}\left(R^{2}=83\right)$. Radial growth of colonies was reduced by $90 \%(\leq 4 \mathrm{~mm})$ after exposure to 29,31 , and $33^{\circ} \mathrm{C}$ for 199,148 , and 
$76 \mathrm{~h}$, respectively, relative to the control maintained at $20^{\circ} \mathrm{C}$.

Clark County solarization trial. Solarization increased maximum soil temperatures 4.1 to $11.7^{\circ} \mathrm{C}$ (Table 1). Mean hourly soil temperatures were $>28.2^{\circ} \mathrm{C}$ at both 10 and $30 \mathrm{~cm}$ soil depth in solarized plots, while mean temperatures in nonsolarized plots did not exceed $23.1^{\circ} \mathrm{C}$. Mean hourly temperature at $30 \mathrm{~cm}$ was $2^{\circ} \mathrm{C}$ greater in solarized, raised bed plots compared to solarized flat bed plots. Approximately 800 cumulative hours with temperature $>29^{\circ} \mathrm{C}$ were recorded at both depths in solarized raised bed plots. Solarized flat bed plots had 655 and 519 cumulative hours $>29^{\circ} \mathrm{C}$ at 10 and $30 \mathrm{~cm}$, respectively. Temperatures exceeded $29^{\circ} \mathrm{C}$ for ca. $100 \mathrm{~h}$ at $10 \mathrm{~cm}$ in nonsolarized plots, but did not reach $29^{\circ} \mathrm{C}$ at $30 \mathrm{~cm}$.

ANOVA of the Clark County data with bed treatments as plots and cultivars as subplots in a split-plot design indicated that bed treatment and cultivar effects were significant for all variables in Table 2 except for 2002 primocane height (differences not significant for both treatment and cultivar) and 2003 yield (differences not significant for cultivar only). Because treatment $\times$ cultivar interaction terms were significant for 2001 primocane weight and for 2003 primocane number, the data for the two cultivars are presented separately in Table 2.

During the 3 years, plant survival, growth, and yield were significantly greater in solarized raised bed plots than in plots receiving other treatments, and 'Willamette' produced more primocanes than 'Malahat'. At the end of 2001, primocane weights of both varieties were greatest $(P$ $<0.05)$ in raised solarized plots with and without gypsum amendment and least in nonsolarized flat bed plots (Table 2). A similar pattern was observed in the number of canes per hill in June 2002, August 2002, and October 2003 (Table 2). By October 2003, few canes of either cultivar survived in flat bed or nonsolarized raised bed plots compared to solarized raised bed plots. In addition, the number of canes per hill was greater in solarized raised bed plots that were amended with gypsum than those without gypsum. Mean cane height of 'Malahat' was greater in solarized raised beds with gypsum amendment than in nonsolarized flat beds without gypsum, but 'Willamette' cane height differences were not as notable. Berry yields in plots of 'Malahat' were 2,658 g and $405 \mathrm{~g}$ in solarized raised beds with and without gypsum amendment, respectively, but less than 100 $\mathrm{g}$ for other treatments. The pattern was similar for 'Willamette' berry yields, but differences were not statistically significant for this variety.

The effects of solarization on the growth of weeds in plots were evident through the first year after planting raspberries. Weed density rating values were lower $(P<0.05)$ in raised bed solarized plots (1.5 to 1.9$)$ than in nonsolarized plots (3.1 to 3.4$)$. In

Table 1. Soil temperatures in solarized and nonsolarized plots at Clark County in 2000 and at Pierce County and Whatcom County in 2002

\begin{tabular}{|c|c|c|c|c|c|c|c|c|c|c|}
\hline \multirow[b]{2}{*}{ Location } & \multirow[b]{2}{*}{ Bed shape } & \multirow[b]{2}{*}{ Solarized } & \multirow[b]{2}{*}{ Depth (cm) } & \multicolumn{2}{|c|}{ Temperature $^{\mathrm{z}}\left({ }^{\circ} \mathrm{C}\right)$} & \multicolumn{5}{|c|}{ Cumulative hours } \\
\hline & & & & Mean & Max & $\mathrm{h}>27^{\circ} \mathrm{C}$ & $\mathrm{h}>29^{\circ} \mathrm{C}$ & $\mathrm{h}>31^{\circ} \mathrm{C}$ & $\mathrm{h}>33^{\circ} \mathrm{C}$ & $\mathrm{h}>35^{\circ} \mathrm{C}$ \\
\hline \multirow[t]{8}{*}{ Clark Co. } & Flat & - & 10 & 23.1 & 32.3 & 214 & 106 & 33 & 0 & 0 \\
\hline & Flat & - & 30 & 22.1 & 28.0 & 1 & 0 & 0 & 0 & 0 \\
\hline & Raised & - & 10 & 22.9 & 32.3 & 213 & 90 & 21 & 0 & 0 \\
\hline & Raised & - & 30 & 23.2 & 26.1 & 0 & 0 & 0 & 0 & 0 \\
\hline & Flat & + & 10 & 31.2 & 41.6 & 848 & 655 & 484 & 383 & 289 \\
\hline & Flat & + & 30 & 28.2 & 32.1 & 940 & 519 & 92 & 0 & 0 \\
\hline & Raised & + & 10 & 32.1 & 44.0 & 927 & 787 & 546 & 443 & 364 \\
\hline & Raised & + & 30 & 30.3 & 35.3 & 926 & 793 & 501 & 188 & 18 \\
\hline \multirow[t]{4}{*}{ Whatcom Co. } & Flat & - & 10 & 18.7 & 28.7 & 21 & 0 & 0 & 0 & 0 \\
\hline & Flat & - & 30 & 18.7 & 26.7 & 0 & 0 & 0 & 0 & 0 \\
\hline & Flat & + & 10 & 28.0 & 42.9 & 816 & 604 & 425 & 293 & 180 \\
\hline & Flat & + & 30 & 25.7 & 31.9 & 532 & 206 & 37 & 0 & 0 \\
\hline \multirow[t]{4}{*}{ Pierce Co. } & Flat & - & 10 & 21.7 & 29.2 & 40 & 3 & 0 & 0 & 0 \\
\hline & Flat & - & 30 & 20.9 & 22.5 & 0 & 0 & 0 & 0 & 0 \\
\hline & Flat & + & 10 & 30.7 & 41.5 & 639 & 434 & 313 & 231 & 131 \\
\hline & Flat & + & 30 & 28.5 & 31.9 & 643 & 345 & 66 & 0 & 0 \\
\hline
\end{tabular}

${ }^{\mathrm{z}}$ Temperatures were recorded hourly by dataloggers. Thermocouples were buried at each depth in one solarized and one nonsolarized plot at each location. Temperature data were collected from 27 July to 20 September 2000 at Clark County, from 23 July to 13 September 2003 at Whatcom County, and only from 22 July to 20 August 2003 at Pierce County because of equipment failure.

Table 2. Effects of soil solarization, bed shape, and amendments of gypsum on the survival, growth, and yield of two root rot susceptible red raspberry cultivars, 'Malahat' and 'Willamette', planted in soil infested with Phytophthora rubi at the Vancouver Research and Extension Center in Clark County, WA

\begin{tabular}{|c|c|c|c|c|c|c|c|c|c|}
\hline \multirow[b]{2}{*}{ Bed shape } & \multirow[b]{2}{*}{ Solarized $^{\mathrm{x}}$} & \multirow[b]{2}{*}{ Gypsum $^{y}$} & \multirow{2}{*}{$\begin{array}{c}\text { Primocane } \\
\text { weight (g) } \\
\text { October } 2001\end{array}$} & \multicolumn{3}{|c|}{ Primocanes per hill } & \multicolumn{2}{|c|}{ Primocane height $(\mathrm{cm})$} & \multirow{2}{*}{$\begin{array}{c}\text { Berry yield } \\
\text { per plot (g) } \\
\text { July } 2003\end{array}$} \\
\hline & & & & June 2002 & August 2002 & October 2003 & October 2002 & October 2003 & \\
\hline \multicolumn{10}{|l|}{ Malahat } \\
\hline Flat & - & - & $39.0 \mathrm{a}^{\mathrm{z}}$ & $1.3 \mathrm{a}$ & $0.5 \mathrm{a}$ & $0.4 \mathrm{a}$ & $70 \mathrm{a}$ & $25 \mathrm{a}$ & $0 \mathrm{a}$ \\
\hline Flat & + & - & $81.4 \mathrm{a}$ & $6.9 \mathrm{ab}$ & $5.6 \mathrm{a}$ & $1.1 \mathrm{a}$ & $88 \mathrm{ab}$ & $206 \mathrm{bc}$ & $13 \mathrm{a}$ \\
\hline Raised & - & - & $84.5 \mathrm{a}$ & $8.1 \mathrm{ab}$ & $5.1 \mathrm{a}$ & $0.3 \mathrm{a}$ & $109 \mathrm{~b}$ & $50 \mathrm{a}$ & $83 \mathrm{a}$ \\
\hline Raised & - & + & $67.0 \mathrm{a}$ & $13.6 \mathrm{~b}$ & $7.7 \mathrm{a}$ & $0.8 \mathrm{a}$ & $104 \mathrm{ab}$ & $113 \mathrm{ab}$ & $48 \mathrm{a}$ \\
\hline Raised & + & - & $282.0 \mathrm{~b}$ & $27.9 \mathrm{c}$ & $30.6 \mathrm{~b}$ & $10.0 \mathrm{~b}$ & $109 \mathrm{~b}$ & $219 \mathrm{bc}$ & $405 \mathrm{a}$ \\
\hline Raised & + & + & $295.0 \mathrm{~b}$ & $26.0 \mathrm{c}$ & $22.9 \mathrm{~b}$ & $15.2 \mathrm{c}$ & $124 \mathrm{~b}$ & $294 \mathrm{c}$ & $2,658 \mathrm{~b}$ \\
\hline \multicolumn{10}{|l|}{ Willamette } \\
\hline Flat & - & - & $113.1 \mathrm{a}$ & $8.0 \mathrm{a}$ & $7.4 \mathrm{a}$ & $2.2 \mathrm{a}$ & 94 & 169 & 160 \\
\hline Flat & + & - & $177.8 \mathrm{a}$ & $10.2 \mathrm{a}$ & $9.2 \mathrm{a}$ & $4.3 \mathrm{a}$ & 125 & 181 & 1,323 \\
\hline Raised & - & - & $198.7 \mathrm{a}$ & $7.4 \mathrm{a}$ & $4.7 \mathrm{a}$ & $0.9 \mathrm{a}$ & 88 & 163 & 8 \\
\hline Raised & - & + & $160.4 \mathrm{a}$ & $17.8 \mathrm{a}$ & $17.1 \mathrm{a}$ & $7.2 \mathrm{a}$ & 126 & 266 & 913 \\
\hline Raised & + & - & $661.8 \mathrm{c}$ & $46.0 \mathrm{~b}$ & $38.4 \mathrm{~b}$ & $25.5 \mathrm{~b}$ & 105 & 288 & 2,048 \\
\hline Raised & + & + & $384.5 \mathrm{~b}$ & $37.4 \mathrm{~b}$ & $37.4 \mathrm{~b}$ & $42.3 \mathrm{c}$ & 118 & 359 & 2,843 \\
\hline
\end{tabular}

x Plots were solarized from 27 July through September 2000. Polyethylene film was left on the soil surface until raspberries were planted in May 2001.

${ }^{y}$ Granular (prilled) agricultural gypsum was applied at $13,450 \mathrm{~kg} / \mathrm{ha}$ and incorporated by rotovating to a depth of $20 \mathrm{~cm}$.

${ }^{\mathrm{z}}$ Mean values within columns followed by different letters were significantly different $(P<0.05)$ according to Fisher's LSD procedure. 
subsequent years, there were no differences in weed densities between treatments.

Pierce and Whatcom county trials. The effects of soil solarization were evident in August 2004, 3 months after planting. The number of primocanes per hill was greater $(P<0.05)$ in plots that were solarized than in nonsolarized plots, but the percentage of surviving hills did not differ between treatments (Table 3). Total length and weight of canes per hill (collected in December) were reduced $>30 \%$ (Whatcom County) and $>60 \%$ (Pierce County) in nonsolarized compared with solarized plots $(P<0.05)$ (Table 3$)$. Applications of fungicides combined with solarization reduced cane lengths of 'Malahat' in Pierce County and 'Qualicum' in Whatcom County. Plant growth was not different between plots in which only fungicides were applied and the nontreated control plots.

In 2005, plant vigor and disease incidence among the treatments were similar at both locations, but disease severity was greater at the Pierce County site. In April, the number of primocanes per hill at Pierce County in solarized 'Qualicum' plots was greater $(P<0.05)$ than in both nonsolarized treatments and in solarized 'Malahat' plots compared to the nontreated plots (Table 4). At Whatcom County, cane stands in solarized plots of 'Qualicum' were not different than those that received only fungicides. In August, the number of primocanes per hill was similar to that in April at both locations, with the greatest number in solarized plots, intermediate number in plot that received only fungicides, and fewest in number in nontreated control plots. More canes survived $(P<$ $0.05)$ in solarized + fungicide plots of 'Qualicum' than in solarized or fungicide only treatments. The percentage of diseased canes was greater in nontreated plots than in plots that received fungicide applications, but only significantly greater $(P<$ $0.05)$ at Pierce County. In December, differences in cane height between treatments were evident at Pierce County where primocanes of 'Qualicum' plants in solarized plots were longer $(P<0.05)$ than those that received only fungicides, and at Whatcom County where canes of 'Malahat' plants in solarized + fungicide treatment were longer $(P<0.05)$ than canes in the other treatments.

In 2006, the final year of the experiment, the survival of plants was extremely low in all plots at both locations (Table 5), indicating that both solarization and fungicide treatments were not sufficient to sustain productivity with these root rot susceptible varieties at these locations. Although there were significant differences between treatments for some parameters, these differences provide little biological information. For example, primocane survival at Pierce County was $\leq 1.5$ canes per hill, which indicates complete failure of all treatments. Primocane survival was better at Whatcom County than at Pierce County.

\section{DISCUSSION}

The effects of elevated temperature and solarization on Phytophthora spp. are well-

Table 3. Effects of soil solarization and application of mefenoxam and fosetyl-Al on survival and primocane growth of two root rot susceptible red raspberry cultivars, 'Malahat' and 'Qualicum', during 2004, the first season after planting in two fields infested with Phytophthora rubi in Washington State

\begin{tabular}{|c|c|c|c|c|c|c|c|c|c|c|}
\hline \multirow[b]{3}{*}{ Location } & \multirow{2}{*}{\multicolumn{2}{|c|}{ Treatment }} & \multicolumn{4}{|c|}{ Malahat } & \multicolumn{4}{|c|}{ Qualicum } \\
\hline & & & \multirow{2}{*}{$\begin{array}{c}\% \text { Hill } \\
\text { survival }^{x}\end{array}$} & \multirow{2}{*}{$\begin{array}{l}\text { Canes } \\
\text { per hill }\end{array}$} & \multirow{2}{*}{$\begin{array}{c}\text { Cane length } \\
(\mathrm{cm})^{\mathrm{y}}\end{array}$} & \multirow{2}{*}{$\begin{array}{c}\text { Cane } \\
\text { weight }(g)^{y}\end{array}$} & \multirow{2}{*}{$\begin{array}{c}\% \text { Hill } \\
\text { survival }^{\mathrm{x}}\end{array}$} & \multirow{2}{*}{$\begin{array}{l}\text { Canes } \\
\text { per hill }\end{array}$} & \multirow{2}{*}{$\begin{array}{l}\text { Cane length } \\
(\mathrm{cm})^{\mathrm{y}}\end{array}$} & \multirow{2}{*}{$\begin{array}{c}\text { Cane } \\
(\mathrm{g})^{\mathrm{y}}\end{array}$} \\
\hline & Solarized $^{v}$ & Fungicide $^{w}$ & & & & & & & & \\
\hline \multicolumn{11}{|l|}{ Pierce Co. } \\
\hline & - & - & 85 & $2.3 \mathrm{a}^{\mathrm{z}}$ & $136 \mathrm{a}$ & $33 \mathrm{a}$ & 100 & $3.1 \mathrm{a}$ & $188 \mathrm{a}$ & $45 \mathrm{a}$ \\
\hline & - & + & 85 & $4.1 \mathrm{a}$ & $123 \mathrm{a}$ & $51 \mathrm{a}$ & 100 & $4.0 \mathrm{ab}$ & $177 \mathrm{a}$ & $70 \mathrm{a}$ \\
\hline & + & - & 90 & $7.5 \mathrm{~b}$ & $642 \mathrm{c}$ & $222 \mathrm{~b}$ & 100 & $5.2 \mathrm{bc}$ & $511 \mathrm{~b}$ & $201 \mathrm{~b}$ \\
\hline & + & + & 90 & $5.2 \mathrm{~b}$ & $475 \mathrm{~b}$ & $156 \mathrm{~b}$ & 100 & $6.0 \mathrm{c}$ & $500 \mathrm{~b}$ & $197 \mathrm{~b}$ \\
\hline \multicolumn{11}{|c|}{ Whatcom Co. } \\
\hline & - & + & 83 & 4.4 & $372 \mathrm{a}$ & $100 \mathrm{a}$ & 100 & $4.3 \mathrm{a}$ & $360 \mathrm{a}$ & $108 \mathrm{a}$ \\
\hline & + & - & 88 & 5.0 & $784 \mathrm{~b}$ & $253 \mathrm{~b}$ & 100 & $7.1 \mathrm{~b}$ & $831 \mathrm{c}$ & $275 \mathrm{~b}$ \\
\hline & + & + & 88 & 4.4 & $736 \mathrm{~b}$ & $226 \mathrm{~b}$ & 100 & $7.2 \mathrm{~b}$ & $697 \mathrm{~b}$ & $233 \mathrm{~b}$ \\
\hline
\end{tabular}

v Plots were solarized from 22 July (Pierce) and 23 July (Whatcom) through September 2003.

${ }^{\mathrm{w}}$ Mefenoxam was applied once and fosetyl-Al twice in the spring and fall each year.

${ }^{x}$ Survival was based on the presence of one or more primocanes per hill.

y Primocanes were cut to the ground in December 2004, and total cane length and weight were recorded.

${ }^{\mathrm{z}}$ Mean values within columns followed by different letters were significantly different $(P<0.05)$ according to Fisher's LSD procedure.

Table 4. Effects of soil solarization and application of mefenoxam and fosetyl-Al on primocane growth and disease incidence of two root rot susceptible red raspberry cultivars, 'Malahat' and 'Qualicum', during 2005, the 2 years after planting in two fields infested with Phytophthora rubi in Washington State

\begin{tabular}{|c|c|c|c|c|c|c|c|c|c|c|}
\hline \multirow[b]{3}{*}{ Location } & \multirow{2}{*}{\multicolumn{2}{|c|}{ Treatment }} & \multirow{2}{*}{\multicolumn{2}{|c|}{$\begin{array}{c}\text { April } 2005 \\
\text { Primocanes per hill }^{\mathrm{u}}\end{array}$}} & \multicolumn{4}{|c|}{ August 2005} & \multirow{2}{*}{\multicolumn{2}{|c|}{$\begin{array}{c}\text { December } 2005 \\
\text { Primocane height }^{\mathrm{w}}(\mathrm{cm})\end{array}$}} \\
\hline & & & & & \multicolumn{2}{|c|}{ Primocanes per hill ${ }^{u}$} & \multicolumn{2}{|c|}{$\%$ Diseased canes ${ }^{v}$} & & \\
\hline & Solarized $^{\mathrm{x}}$ & Fungicide $^{y}$ & Malahat & Qualicum & Malahat & Qualicum & Malahat & Qualicum & Malahat & Qualicum \\
\hline \multicolumn{11}{|l|}{ Pierce Co. } \\
\hline & - & - & $14.2 \mathrm{a}^{\mathrm{z}}$ & $11.7 \mathrm{a}$ & $6 \mathrm{a}$ & $2 \mathrm{a}$ & $14.8 \mathrm{c}$ & $27.5 \mathrm{~b}$ & $81 \mathrm{a}$ & $67 \mathrm{a}$ \\
\hline & - & + & $19.5 \mathrm{ab}$ & $15.6 \mathrm{a}$ & $19 \mathrm{ab}$ & $21 \mathrm{~b}$ & $1.6 \mathrm{ab}$ & $2.5 \mathrm{a}$ & $103 \mathrm{bc}$ & $99 \mathrm{~b}$ \\
\hline & + & - & $41.5 \mathrm{~b}$ & $27.3 \mathrm{~b}$ & $31 \mathrm{~b}$ & $30 \mathrm{bc}$ & $13.3 \mathrm{bc}$ & $2.0 \mathrm{a}$ & $92 \mathrm{ab}$ & $117 \mathrm{c}$ \\
\hline & + & + & $35.6 \mathrm{~b}$ & $31.5 \mathrm{~b}$ & $33 \mathrm{~b}$ & $35 \mathrm{c}$ & $0.1 \mathrm{a}$ & $1.5 \mathrm{a}$ & $111 \mathrm{c}$ & $118 \mathrm{c}$ \\
\hline \multicolumn{11}{|c|}{ Whatcom Co. } \\
\hline & - & + & 28.9 & $25.0 \mathrm{ab}$ & 26 & $27 \mathrm{~b}$ & $0.5 \mathrm{a}$ & 1.0 & $142 \mathrm{a}$ & $157 \mathrm{ab}$ \\
\hline & + & - & 29.0 & $34.7 \mathrm{~b}$ & 26 & $35 \mathrm{bc}$ & $8.3 \mathrm{ab}$ & 4.3 & $155 \mathrm{a}$ & $159 \mathrm{ab}$ \\
\hline & + & + & 26.8 & $33.4 \mathrm{~b}$ & 29 & $42 \mathrm{c}$ & $0.3 \mathrm{a}$ & 1.3 & $162 \mathrm{~b}$ & $166 \mathrm{~b}$ \\
\hline
\end{tabular}

\footnotetext{
" Survival was based on the presence of one or more primocanes per hill.

${ }^{v}$ Percentage of canes with symptoms of raspberry root rot.

${ }^{\mathrm{w}}$ Height of 50 primocanes was measured in two 50-m lengths of the row of each cultivar in the plots.

${ }^{x}$ Plots were solarized from 22 July (Pierce) and 23 July (Whatcom) through September 2003.

${ }^{\mathrm{y}}$ Mefenoxam was applied once and fosetyl-Al twice in spring and fall each year.

${ }^{\mathrm{z}}$ Mean values within columns followed by different letters were significantly different $(P<0.05)$ according to Fisher's LSD procedure.
} 
documented $(1,2,5,16,20,22,23)$. Wilcox reported that the optimal temperature for colony growth of a Chilean isolate of $P$. rubi on V8 juice agar was 22 to $25^{\circ} \mathrm{C}$ and no colony growth was observed after 9 days at $28^{\circ} \mathrm{C}$ (37). Pullman et al. (25) reported a logarithmic relationship between time and temperature (thermal dose) on the death of four soilborne plant pathogens. We observed no mycelial growth at $29^{\circ} \mathrm{C}$ after $240 \mathrm{~h}$, but after incubation for shorter duration at $29^{\circ} \mathrm{C}$, colonies resumed growth when transferred to the optimal temperature for growth. Exposure to sublethal thermal doses reduced greatly the radial growth of colonies incubated subsequently at $20^{\circ} \mathrm{C}$. Freeman and Katan (13) reported that sublethal temperatures may adversely affect spore viability of Fusarium expressed as delayed germination and germ tube growth. They suggest that biological control activities of soil bacteria may be responsible for reduced viability of weakened propagules. Sublethal temperature treatment of microsclerotia of Verticillium dahliae reduced the rate of germination, production of melanized microsclerotia, and made microsclerotia more susceptible to the biocontrol fungus Talaromyces flavus (32). We do not know whether exposure to temperatures less than $29^{\circ} \mathrm{C}$ for 222 $\mathrm{h}$, the lethal exposure in the in vitro study, will suppress $P$. rubi oospore germination and disease development in raspberry fields. The in vitro study supports our field data, but it is not by itself sufficient to predict field performance elsewhere. Temperatures in the in vitro study were continuous, whereas soil temperatures are variable, particularly in the upper $10 \mathrm{~cm}$. Furthermore, our lethal exposure was based upon vegetative growth, and oospores may be more heat tolerant. However, Duncan reported the $P$. fragariae infectivity was lost rapidly at $30^{\circ} \mathrm{C}$, and prolonged exposure to $30^{\circ} \mathrm{C}$ killed oospores $(9,10)$. In our in vitro study, mycelia were killed by exposure to $35^{\circ} \mathrm{C}$ for $52 \mathrm{~h}$.
Similarly, Duncan (7) reported that oospores were killed by exposure to $35^{\circ} \mathrm{C}$ for $24 \mathrm{~h}$.

Previous experiments demonstrated that solarization can suppress several soilborne plant pathogens under conditions in Oregon and southwestern Washington $(22,23)$. Root rot of strawberry and raspberry were significantly reduced in solarized plots where cumulative hours of temperature $>30^{\circ} \mathrm{C}$ were $794 \mathrm{~h}$ at $20 \mathrm{~cm}$ depth and 221 $\mathrm{h}$ at $30 \mathrm{~cm}$, respectively (23). In our current research, cumulative hour $>29^{\circ} \mathrm{C}$ at 30 $\mathrm{cm}$ soil depth ranged from 206 to $793 \mathrm{~h}$, thermal doses that exceed lethal level for $P$. rubi colonies in the laboratory study (Table 1). Nearly continuous periods of soil temperatures $>29^{\circ} \mathrm{C}$ occurred at $30 \mathrm{~cm}$ in August and were only separated by very brief periods when temperatures ranged between 27 and $29^{\circ} \mathrm{C}$ (data not presented). Fluctuation of diurnal temperatures was more pronounced at the $10 \mathrm{~cm}$ soil depth, but temperature maximums were greatest at this depth, with recorded temperatures $>35^{\circ} \mathrm{C}$ for 131 to $364 \mathrm{~h}$ (Table 1 ). These durations $>35^{\circ} \mathrm{C}$ are much greater than those calculated to be lethal for vegetative growth in the in vitro study and much greater than those reported to be lethal to $P$. fragariae oospores (7). We recorded temperatures 2 to $3^{\circ} \mathrm{C}$ higher and an additional $274 \mathrm{~h}>29^{\circ} \mathrm{C}$ at $30 \mathrm{~cm}$ in raised bed compared to flat beds, while temperatures at $30 \mathrm{~cm}$ did not reach $35^{\circ} \mathrm{C}$ in solarized flat beds and were $>35^{\circ} \mathrm{C}$ for only $18 \mathrm{~h}$ in solarized raised beds. Chellemi et al. (4) observed a similar 2 to $4^{\circ} \mathrm{C}$ difference between solarized flat and raised beds and noted that raised beds eliminated the border effects associated with solarization. We believe that the additional temperature gain was due to morning and afternoon solar heating of the sides of the raised beds, which were orientated in north-south rows. The decline of raspberry stands in solarized plots in the third year may be a function of roots growing into soil depths where thermal dose was insufficient to reduce inoculum density of $P$. rubi. The third year is also the first year of full crop production for floricane-bearing varieties like 'Malahat' and 'Qualicum', so the collapse in this year could result from the stress of a full fruit load on plants with PRR-compromised root systems.

Climatic conditions can have a significant effect on the development of PRR of raspberry (18). In the Whatcom and Pierce experiments, plant stands in the solarization plots were denser and canes more vigorous in plots that were solarized compared to nonsolarized plots during the first 2 years after planting. In the third season, conditions were very conducive for the development of PRR $(10,11)$. Precipitation was recorded on 90 days during the first 6 months of 2006 and the mean percent soil moisture was $>24 \%$ during this period (AgWeatherNet, WSU, Prosser, WA). Mean soil temperature at $20 \mathrm{~cm}$ depth during the spring of 2006 was $12.2^{\circ} \mathrm{C}$ ( 6 to $16^{\circ} \mathrm{C}$ ) and $12.5^{\circ} \mathrm{C}\left(7\right.$ to $\left.19^{\circ} \mathrm{C}\right)$ at Pierce County and Whatcom County, respectively. During harvest in late June and early July, an unusual period of high temperatures (air temperature max. $34^{\circ} \mathrm{C}$ ) and dry conditions stressed the plants, which wilted rapidly. These conditions resulted in very low survival of primocanes in the Pierce County plots where there was very high disease pressure. Substantial primocane mortality also was observed in the Whatcom County plots. Even PRR tolerant genotypes in the raspberry breeder's trial adjacent to the Pierce County plots showed PRR symptoms under the high disease pressure and stressful conditions (P. Moore, personal communication).

The management of PRR in raspberry requires a multifaceted approach. Wilcox et al. (38) reported that raised beds consistently improved raspberry yield compared to flat beds. Metalaxyl was least effective under high root rot pressure, initially improving yield of a susceptible variety, but

Table 5. Effects of soil solarization and application of mefenoxam and fosetyl-Al on primocane survival, growth, and fruit yield of two root rot susceptible red raspberry cultivars, 'Malahat' and 'Qualicum', in July 2006, 3 years after planting in Phytophthora rubi infested fields at two locations in Washington State

\begin{tabular}{|c|c|c|c|c|c|c|c|c|}
\hline \multirow[b]{2}{*}{ Location } & \multicolumn{2}{|c|}{ Treatment } & \multicolumn{2}{|c|}{ Berry yield $^{v}$} & \multicolumn{2}{|c|}{ Primocanes per hill ${ }^{w}$} & \multicolumn{2}{|c|}{ Primocanes height $(\mathbf{c m})^{\mathrm{w}}$} \\
\hline & Solarized $^{\mathrm{x}}$ & Fungicide $^{y}$ & Malahat & Qualicum & Malahat & Qualicum & Malahat & Qualicum \\
\hline \multicolumn{9}{|l|}{ Pierce Co. } \\
\hline & - & - & 1.0 & $1.0 \mathrm{a}^{\mathrm{z}}$ & $0.0 \mathrm{a}$ & $0.0 \mathrm{a}$ & 0.0 & $2.0 \mathrm{a}$ \\
\hline & - & + & 1.3 & $4.5 \mathrm{~b}$ & $0.8 \mathrm{~b}$ & $1.5 \mathrm{~b}$ & 0.0 & $56.0 \mathrm{~b}$ \\
\hline & + & - & 1.0 & $2.3 \mathrm{ab}$ & $0.1 \mathrm{a}$ & $0.3 \mathrm{a}$ & 0.0 & $14.0 \mathrm{ab}$ \\
\hline & + & + & 1.3 & $3.8 \mathrm{ab}$ & $0.1 \mathrm{a}$ & $0.3 \mathrm{a}$ & 1.0 & $34.8 \mathrm{ab}$ \\
\hline \multicolumn{9}{|c|}{ Whatcom Co. } \\
\hline & - & - & 1,190 & 1,880 & 1.6 & 6.5 & 12.0 & $31.2 \mathrm{a}$ \\
\hline & - & + & 1,410 & 3,660 & 3.1 & 10.7 & 21.9 & $54.9 \mathrm{~b}$ \\
\hline & + & - & 1,610 & 3,900 & 1.1 & 7.2 & 10.7 & $43.7 \mathrm{ab}$ \\
\hline & + & + & 2,440 & 3,850 & 3.1 & 10.4 & 23.4 & $54.9 \mathrm{~b}$ \\
\hline
\end{tabular}

\footnotetext{
${ }^{\mathrm{v}}$ Whatcom plots were machine harvested on three dates between 22 June and 18 July 2006. Berry yield is total berry weight (g) from the three harvests. At Pierce Co., the fruit load was estimated on 28 June plots and rated $1=$ no fruit to $10=$ typical commercial fruit load.

${ }^{\text {w }}$ Number and mean heights of primocanes $>8 \mathrm{~mm}$ diameter was recorded on 7 July 2006 at both locations.

x Plots were solarized from 22 July (Pierce) and 23 July (Whatcom) through September 2003.

${ }^{\mathrm{y}}$ Mefenoxam was applied once and fosetyl-Al twice in spring and fall each year.

${ }^{\mathrm{z}}$ Mean values within columns followed by different letters were significantly different $(P<0.05)$ according to Fisher's LSD procedure.
} 
plants died the second year. They later reported gypsum amendments produced the best yield, better than metalaxyl, and that raised beds were not as effective with highly susceptible cultivars (18). They recommended an integrated program for managing raspberry root rot that included raised beds, gypsum amendments, fungicide applications, and planting more tolerant varieties. In the Clark County trial, we observed the greatest plant survival and fruit yield in plots with solarized raised beds in which soil was amended with gypsum. Hilling reduces waterlogging, making soil conditions less conducive for root rot. In addition, the calcium ions from gypsum can restrict the liberation and movement of zoospores and disease development (39). In our trials, soil solarization probably reduced the inoculum potential of $P$. rubi, thus complimenting the effects of raised beds and gypsum. The varieties that we planted were very susceptible to $P$. rubi $(3,31)$ and the sites had high inoculum potential, so symptoms of root rot became evident in the third year, with PRR symptoms evident in all plots. Under such conditions, applications of mefenoxam and fosetyl-Al were ineffective in reducing PRR, as reported in New York (18).

Soil solarization has been reported to be as effective as methyl bromide fumigation (15) and metalaxyl (34) for control of Phytophthora root diseases. Our research demonstrated that solarization initially can suppress PRR, but solarization and chemical control were not sufficient to maintain productivity past the second year with susceptible varieties and high disease pressure. Other inputs are needed to maintain plant vigor and yield. An integrated program for management of PRR would combine solarization with root rot tolerant varieties, raised beds, gypsum amendments, and applications of fungicides. Solarization can be combined with fumigation (4), cultural practices (26,30), and biological control $(24,32,33)$. Solarization is particularly attractive for small fruit production systems because the polyethylene tarp can be left on the soil surface after solar heating, followed by planting through this plastic mulch for extended weed control and increased soil temperature for early season root development.

\section{ACKNOWLEDGMENTS}

We thank Tim Lair, Charles Hand, and Megan Kitner for technical assistance with aspects of this research. The research was funded in part by USDA Northwest Center for Small Fruit Research. Raspberry plants were provided gratis by Sakuma Bros. Farms Inc., Burlington, WA.

\section{LITERATURE CITED}

1. Barbercheck, M. E., and von Broembsen, S. L. 1986. Effects of soil solarization on plant parasitic nematodes and Phytophthora cinnamomi in South Africa. Plant Dis. 70:945-950.
2. Benson, D. M. 1978. Thermal inactivation of Phytophthora cinnamomi for control of Fraser Fir root rot. Phytopathology 68:1373-1376.

3. Bristow, P. R., Daubeny, H. A., Sjulin, T. M., Pepin, H. S., Nestby, R., and Windom, G. E. 1988. Evaluation of Rubus germplasm for reaction to root rot caused by Phytophthora erythroseptica. J. Am. Soc. Hortic. Sci. 113:588-591.

4. Chellemi, D. O., Olson, S. M., Mitchell, D. J., Secker, I., and McSorley, R. 1997. Adaptation of soil solarization to the integrated management of soilborne pests of tomato under humid conditions. Phytopathology 87:250-258.

5. Coelho, L., Mitchell, D. J., and Chellemi, D. O. 2000. Thermal inactivation of Phytophthora nicotianae. Phytopathology 90:1089-1097.

6. Converse, R. H., and Schwartz, C. D. 1968. A root rot of red raspberry caused by $P h y$ tophthora erythroseptica. Phytopathology 58:56-59.

7. Duncan, J. M. 1977. Germination in vitro of Phytophthora fragariae oospores from infected root tissue Trans. Br. Mycol. Soc. 69:391-395.

8. Duncan, J. M. 1980. Persistence of mycelium of Phytophthora fragariae in soil. Trans. Br. Mycol. Soc. 75:383-387.

9. Duncan, J. M. 1985. Effect of temperature and other factors on in vitro germination of Phytophthora fragariae oospores. Trans. Br. Mycol. Soc. 85:455-462.

10. Duncan, J. M., and Cowan, J. B. 1980. Effect of temperature and soil moisture content on persistence of infectivity of Phytophthora fragariae in naturally infested field soil. Trans. Br. Mycol. Soc. 75:133-139.

11. Duncan, J. M., and Kennedy, D. M. 1989. The effect of waterlogging on Phytophthora root rot of red raspberry. Plant Pathol. 38:161-168.

12. Duncan, J. M., Kennedy, D. M., and Seemüller, E. 1987. Identities and pathogenicities of Phytopthtora spp. causing root rot of red raspberry. Plant Pathol. 36:276-289.

13. Freeman, S., and Katan, J. 1988. Weakening effect on propagules of Fusarium by sublethal heating. Phytopathology 78:1656-1661.

14. Greenberger, A., Yogev, A., and Katan, J. 1987. Induced suppressiveness in solarized soils. Phytopathology 77:1663-1667.

15. Johnson, F., Crandall, P. C., and Fisher, J. R. 1973. Soil fumigation and its effect on raspberry root rot. Plant Dis. Rep. 56:467-470.

16. Juarez-Palacios, C., Felix-Gastelum, R., Wakeman, R. J., Paplomatas, E. J., and DeVay, J. E. 1991. Thermal sensitivity of three species of Phytophthora and the effect of soil solarization on their survival. Plant Dis. 75:1160-1164.

17. Katan, J. 1981. Solar heating (solarization) of the soil for control of soilborne pests. Annu. Rev. Phytopathol. 19:211-236.

18. Maloney, K., Pritts, M., Wilcox, W., and Kelly, M. J. 2005. Supression of Phytophthora root rot in red raspberries with cultural practice and soil amendments. HortScience 40:1790-1795.

19. Montgomerie, I. G., and Kennedy, D. M. 1980. The pathogenicity of Phytophthora species to red raspberry. Acta Hortic. 112:167-176.

20. Nesbitt, H. J., Malajcuk, N., and Glenn, A. R. 1979. Effect of soil moisture and temperature on the survival of Phytophthora cinnamomi Rands in soil. Soil Biol. Biochem. 11:137-140.

21. Peachy, R. E., Pinkerton, J. N., Ivors, K. L., Miller, M. L., and Moore, L. W. 2001. Effect of soil solarization, cover crops, and metham on field emergence and survival of buried annual bluegrass (Poа апnиа) seeds. Weed Technol. 15:81-88.

22. Pinkerton, J. N., Ivors, K. L., Miller, M. L., and Moore, L. W. 2000. Effect of soil solarization and cover crops on populations of selected soilborne plant pathogens in western Oregon. Plant Dis. 84:952-960.

23. Pinkerton, J. N., Ivors, K. L., Reeser, P. W. Bristow, P. R., and Windom, G. E. 2002. The use of soil solarization for the management of soilborne plant pathogens in strawberry and red raspberry production. Plant Dis. 86:645651.

24. Porras, M., Barrau, C., and Romero, F. 2007. Effects of solarization and Trichoderma on strawberry production. Crop Prot. 26:782-787.

25. Pullman, G. S., DeVay, J. E., and Garber, R. H. 1981. Soil solarization and thermal death: Logarithmic relationship between time and temperature for four soilborne plant pathogens. Phytopathology 71:959-964.

26. Ramirez-Villapudua, R. J., and Munnecke, D. E. 1988. Effect of solar heating and soil amendments of cruciferous residues on Fusarium oxysporum f. s. conglutinans and other organisms. Phytopathology 78:289-295.

27. Reeser, P. W., and Pscheidt, J. W. 1996. Insensitivity to metalaxyl in isolates of Phy tophthora fragariae var. fragariae from strawberry in Oregon. (Abstr.) Phytopathology 86:S111.

28. Scheer, W. P. A., and Garren, R. 1981. Commercial Red Raspberry Production. Wash. State Univ., Oregon State Univ., and Univ. Idaho, PNW Bull. 176.

29. Stapleton, J. J., and DeVay, J. E. 1984. Thermal components of soil solarization as related to exchange in soil and root microflora and in creased plant growth response. Phytopathology $74: 255-259$

30. Stevens, C., Khan, V. A., Rodriguez-Kabana, R., Ploper, L. D., Backman, P. A., Collins, D. J., Brown, J. E., Wilson, M. A., and Igwegbe, E. C. K. 2003. Integration of soil solarization with chemical, biological, and cultural control for management of soilborne diseases of vegetables. Plant Soil 253:493-506.

31. Strik, B. C. 1998. Red raspberry cultivars for Oregon. EC 1310. Extension and Station Communications, Oregon State University, Corvallis.

32. Tjamos, E. C., and Fravel, D. R. 1995. Detrimental effects of sublethal heating and Talaromyces flavus on microsclerotia of Verticillium dahliae. Phytopathology 85:388-392.

33. Toussaint, V., Valios, D., Dodier, M., Faucher, E., Déry, C., Brzezinski, R., Ruest, L., and Beaulieu, C. 1997. Characterization of actinomycetes antagonistic to Phytophthora fragariae pv. rubi, the causal agent of raspberry root rot. Phytoprotection 78:43-51.

34. Wicks, T. J. 1988. Effect of solarization on the control of Phytophthora cambivora in almond and cherry. Aust. J. Exp. Agric. 28:539-545.

35. Wilcox, W. F. 1989. Identity, virulence, and isolation frequency of seven Phythopthora spp. Causing root rot of raspberry in New York. Phytopathology 79:93-101.

36. Wilcox, W. F. 1991. Phytophthora root rot. Pages 34-36 in: Compendium of Raspberry and Blackberry diSeases and Insects. M. A Ellis, R. H. Converse, R. N. Williams, and B Williamson, eds. American Phytopathological Society, St. Paul, MN

37. Wilcox, W. F, and Latorre, B. A. 2002. Identities and geographic distributions of Phy tophthora spp. causing root rot of red raspberry in Chile. Plant Dis. 86:1357-1362.

38. Wilcox, W. F., Pritts, M. P., and Kelly, M. J. 1999. Integrated control of Phytophthora root rot of red raspberry. Plant Dis. 83:1149-1154.

39. Xu-Chang and Morris, P. F. 1998. External calcium controls the developmental strategy of Phytophthora sojae cysts. Mycologia 90:269 275. 